\title{
Article \\ Effect of Rheology of Fresh Paste on the Pore Structure and Properties of Pervious Concrete Based on the High Fluidity Alkali-Activated Slag
}

\author{
Haining Geng ${ }^{1,+}$, Qing Xu ${ }^{2,+}$, Saiful B. Duraman ${ }^{3}$ and Qiu Li ${ }^{2, *(D)}$ \\ 1 Hubei Urban Construction Vocational and Technological College, Wuhan 430205, China; ghn_007@126.com \\ 2 State Key Laboratory of Silicate Materials for Architectures, Wuhan University of Technology, \\ Wuhan 430070, China; tom_xu@smatmicrotech.com \\ 3 Civil Engineering Programmes, Faculty of Engineering, Universiti Teknologi Brunei, \\ Bandar Seri Begawan BE 1410, Brunei; saiful.duraman@utb.edu.bn \\ * Correspondence: Qiu-Li@whut.edu.cn \\ + These authors equally contributed to this work and share the first authorship.
}

check for updates

Citation: Geng, H.; Xu, Q.; Duraman, S.B.; Li, Q. Effect of Rheology of Fresh Paste on the Pore Structure and Properties of Pervious Concrete Based on the High Fluidity Alkali-Activated Slag. Crystals 2021, 11, 593. https:// doi.org/10.3390/cryst11060593

Academic Editors: Nichola Coleman, Samantha E. Booth and

Nima Farzadnia

Received: 8 February 2021

Accepted: 19 May 2021

Published: 24 May 2021

Publisher's Note: MDPI stays neutral with regard to jurisdictional claims in published maps and institutional affiliations.

Copyright: (c) 2021 by the authors. Licensee MDPI, Basel, Switzerland. This article is an open access article distributed under the terms and conditions of the Creative Commons Attribution (CC BY) license (https:// creativecommons.org/licenses/by/ $4.0 /)$.

\begin{abstract}
Pervious concrete is made of cementitious materials, coarse aggregate, water and additives, with characteristic macro- and meso-connected pore structure, which enables the acceptable mechanical properties and high water permeability for pavement and road applications. In this study, the effect of rheology of fresh alkali-activated slag paste on the sedimentation of paste on the bottom of pervious concrete, meso-structure, connected porosity, mechanical properties and water permeability was investigated by a range of analytical techniques through varying the equivalent alkali content to control the rheology of fresh paste in the pervious concrete. The compressive strength of pervious concrete was related to the percentage area of paste and the average thickness of paste on the surface of coarse aggregate. The tensile strength and water permeability were correlated to the connected porosity of pervious concrete and the rheology of fresh paste. A relative lower fluidity, higher viscosity and shear stress of fresh alkali-activated slag paste favoured lower sedimentation of paste on the bottom of pervious concrete, higher connected porosity, tensile strength and water permeability. There was no correlation between compressive strength and tensile strength of pervious concrete.
\end{abstract}

Keywords: rheology; sedimentation; thickness of paste; connected porosity; water permeability

\section{Introduction}

Pervious concrete is an eco-friendly construction material that consists of cementitious materials, coarse aggregate, water and additives [1]. The characteristic connected macropore structure of pervious concrete enables the high water permeability and acceptable mechanical properties as pavement materials, which are widely used in car parks, gardens and sometimes roads [2,3]. The porosity of pervious concrete is usually between $15 \%$ and $35 \%$, with a water permeability of $2-70 \mathrm{~mm} \cdot \mathrm{s}^{-1}$, compressive strength of $5-30 \mathrm{MPa}$ and tensile strength of 2-5 MPa [4-10]. Pervious concrete could also immobilize heavy metals in the water, absorb noise and isolate heat, according to previous studies [11-15].

Alkali-activated materials are made of alkali-activators and aluminosilicate materials as precursors, which react to form $\mathrm{Si}-\mathrm{O}-\mathrm{Al}$ bonding in the materials [16-20]. The most common alkali activators include sodium hydroxide, sodium silicate, sodium sulphate and their potassium counterparts. The aluminosilicate precursors are usually natural minerals or industrial by-products, such as calcined clay, metakaolin, fly ash, bottom ash, slag and rice husk ash. Due to the industrial by-products' nature as the precursors of alkali-activated materials, pervious concrete is usually treated as an eco-friendly construction materials that could potentially partially or even fully replace Portland cement in the future [21]. High early and late age strength, low creep and shrinkage and high sulphate resistance are the characteristic advantages of alkali-activated materials [20,22-26]. There are also 
disadvantages associated with the alkali-activated materials, such as efflorescence during the service life and higher risk in handling alkaline solutions during preparation.

The fluidity, viscosity of the fresh paste, setting time and mechanical properties of alkali-activated materials were affected by the equivalent alkali content, modulus of water glass and water:binder ratio [19,27-32]. A previous study on the equivalent alkali content and modulus of activator on the properties of fresh paste suggested that the fluidity changed with the increase in equivalent alkali content [27]. Another research on the relationship between the fresh and hardened properties and the equivalent alkali content suggested that the fluidity and compressive strength increased with the equivalent alkali content [33]. The differences of rheology between various cementitious materials were also investigated and the results indicated that the shear stress of water glass-activated slag was higher than that of Portland cement and sodium hydroxide-activated slag, which could be related to the formation of C-S-H in the former [30].

Preparing pervious concrete with alkali-activated materials has been investigated previously [13], and the mechanical properties, water permeability, durability and heavy metal removal efficiency of alkali-activated fly ash-based pervious concrete have been reported. There are also researches focused on the macro- and mesopore structures of pervious concrete [34], which is vital for the properties. The macropores are in the size of centimetres and the mesopores are in the size of millimetres. The macro- and mesopore structure of pervious concrete defines the mechanical properties and water permeability. Due to the nature of mesostructure of pervious concrete, where layers of cementitious materials cover the surface of coarse aggregate [34], the rheology properties of cementitious materials are important for the pervious concrete as they control the homogeneity, thickness of paste on the surface of aggregate and the connected pore structure, which in turn affects the mechanical properties and water permeability of pervious concrete $[4,5,8,15]$. However, there are few literatures on the effect of fluidity and rheology of alkali-activated materials on the mesostructure of pervious concrete, particularly the properties of it.

In this study, aiming to utilize the industrial by-product so as to reduce the energy demand of Portland cement production and save resources, pervious concrete was designed and prepared by using alkali-activated slag as cementitious materials, and the effect of equivalent alkali content (as $\mathrm{Na}_{2} \mathrm{O}$ content) of paste in pervious concrete on the rheology of paste, sedimentation of paste on the bottom of pervious concrete, mesostructures, mechanical properties and water permeability of pervious concrete were investigated by a range of analytical techniques. The relationship between the rheology of paste and the sedimentation of paste on the bottom of pervious concrete, the mesostructure and the thickness distribution of paste were discussed. The aim of this study is to shed some light on the relationship between the rheology of paste and the meso- and macrostructure of pervious concrete, particularly the mechanical properties and water permeability.

\section{Materials and Methods}

\subsection{Materials}

Ground granulated blast furnace slag of grade S95 from Huaxin Cement Co., Yichang, China, was used as precursor in this study. The chemical composition and particle size distribution are shown in Table 1 and Figure 1, respectively. The particle size distribution of slag was characterized by Malvern Mastersizer 2000 laser diffraction particle size analyser (Malvern Panalytical, Malvern, UK) through dispersing slag particles in water.

Table 1. Chemical composition of slag.

\begin{tabular}{cccccccccc}
\hline Oxide & $\mathrm{CaO}$ & $\mathrm{Si}_{2} \mathrm{O}$ & $\mathrm{Al}_{2} \mathrm{O}_{3}$ & $\mathrm{MgO}$ & $\mathrm{SO}_{3}$ & $\mathrm{TiO}_{2}$ & $\mathrm{Fe}_{2} \mathrm{O}_{3}$ & $\mathrm{Na}_{2} \mathrm{O}$ & L.O.I. ${ }^{*}$ \\
\hline $\mathrm{wt} \%$ & 38.7 & 35.5 & 14.8 & 6.7 & 2.2 & 0.79 & 0.27 & 0.26 & 0.88 \\
\hline
\end{tabular}

${ }^{*}$ L.O.I.: loss on ignition. 


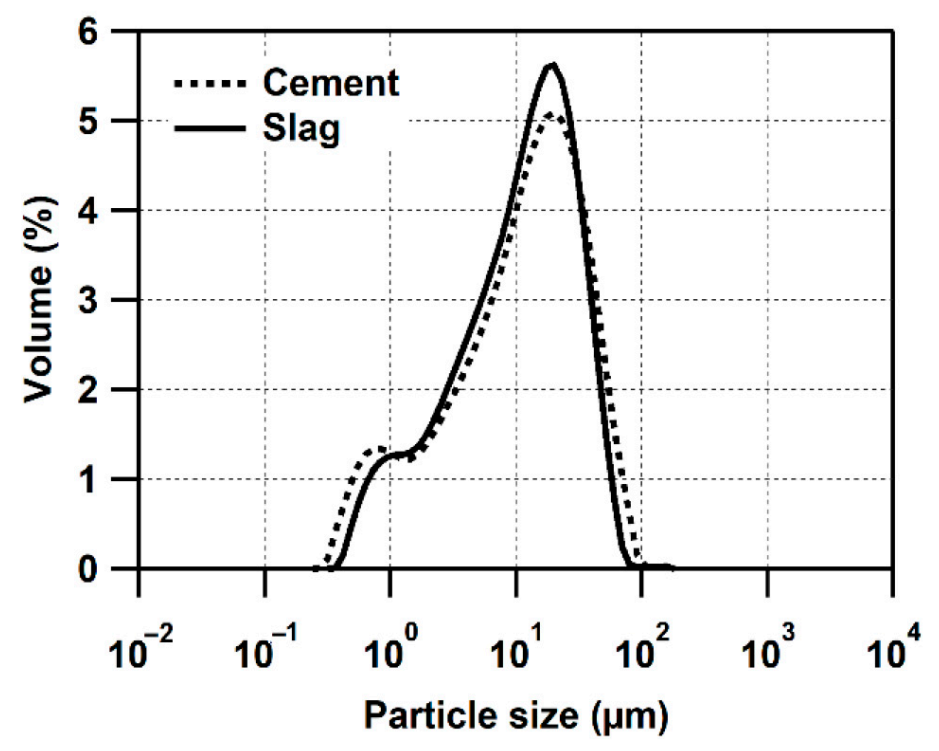

Figure 1. Particle sized distribution of slag used in this study.

The particle size distribution of slag is similar to that of Portland cement. Chemical and physical properties of water glass used are shown in Table 2, which were provided by the supplier. Industrial grade sodium hydroxide with purity of $99 \%$ from Yihua Chemicals Co., Xining, China, was used in this study. AR grade calcium gluconate from Sinopharm, Shanghai, China, was used as retarder in this study. Limestone coarse aggregate in the size of 4.75-9.5 mm from Wuhan, China, was used in this study (Figure 2), and the properties are shown in Table 3, which were tested according to Chinese standard GB/T 14685-2011 [35].

Table 2. Chemical and physical properties of water glass.

\begin{tabular}{ccccccc}
\hline Modulus & $\begin{array}{c}\text { Solid } \\
\text { Content }\end{array}$ & $\begin{array}{c}\mathrm{Na}_{2} \mathrm{O} \\
\text { Content }\end{array}$ & $\begin{array}{c}\text { SiO } \\
\text { Content }\end{array}$ & Density & Transparency & $\begin{array}{c}\mathrm{Fe} \\
\text { Content }\end{array}$ \\
\hline 2.2 & $53 \mathrm{wt} \%$ & $24.5 \mathrm{wt} \%$ & $53.9 \mathrm{wt} \%$ & $1495 \mathrm{~kg} / \mathrm{m}^{3}$ & $88 \%$ & $0.08 \%$ \\
\hline
\end{tabular}

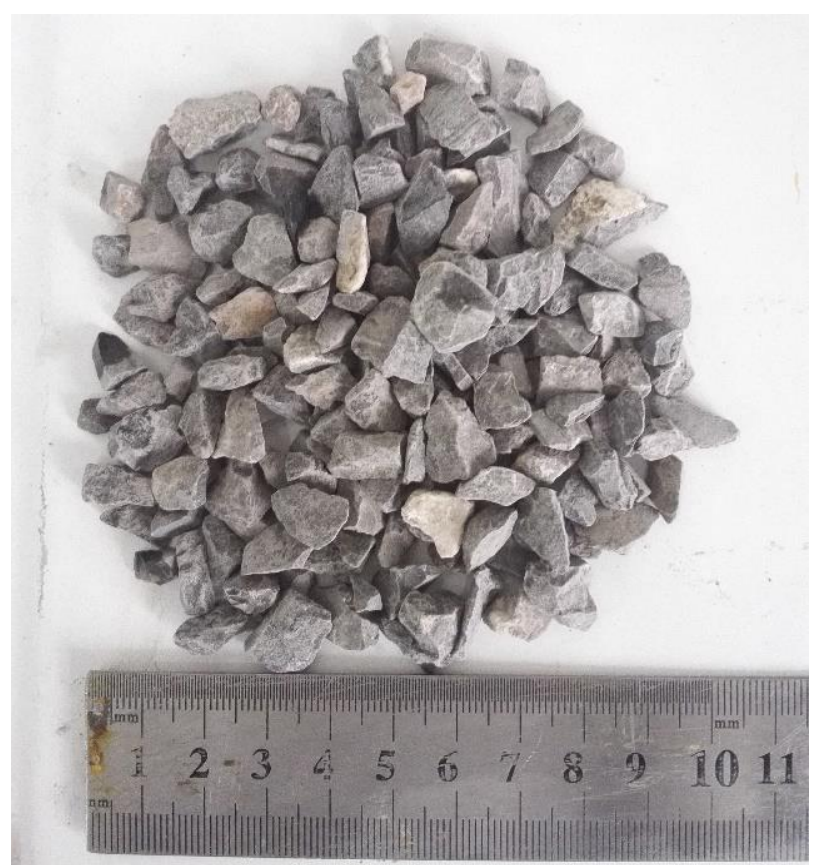

Figure 2. Image of limestone coarse aggregate used in this study. 
Table 3. Properties of coarse aggregate.

\begin{tabular}{cccccc}
\hline Type & $\begin{array}{c}\text { Bulk } \\
\text { Density }\end{array}$ & $\begin{array}{c}\text { Apparent } \\
\text { Density }\end{array}$ & $\begin{array}{c}\text { Crushing } \\
\text { Value }\end{array}$ & $\begin{array}{c}\text { Water } \\
\text { Absorption }\end{array}$ & $\begin{array}{c}\text { Moisture } \\
\text { Content }\end{array}$ \\
\hline Limestone & $1560.5 \mathrm{~kg} / \mathrm{m}^{3}$ & $2680 \mathrm{~kg} / \mathrm{m}^{3}$ & $4.57 \%$ & $3.2 \%$ & $0.3 \%$ \\
\hline
\end{tabular}

\subsection{Experimental Details}

\subsubsection{Specimen Preparation}

The mix design of pervious concrete with various equivalent alkali content is shown in Table 4. The water:slag ratio was set to 0.3. The method of mix design of pervious concrete followed the previous study by Sun [36]. The microstructure of pervious concrete was separated into various components, from which the volumes of components were calculated, as shown in Figure 3.

Table 4. Mix design of pervious concrete $\left(\mathrm{kg} / \mathrm{m}^{3}\right)$.

\begin{tabular}{ccccccccc}
\hline Mix & Slag & $\begin{array}{c}\text { Equivalent } \mathrm{Na}_{2} \mathbf{O} \\
\text { Content }\end{array}$ & NaOH & Water Glass & Retarder & Water & Aggregate & DVR \& \\
\hline A4 & 305 & $4 \%$ & 5.01 & 49.11 & 0.3 & 68.42 & 1529 \\
A6 & 305 & $6 \%$ & 7.51 & 73.66 & 0.3 & 56.88 & 1529 & $22 \%$ \\
A8 & 305 & $8 \%$ & 10.02 & 98.22 & 0.3 & 45.34 & 1529 & $21 \%$ \\
A10 & 305 & $10 \%$ & 12.52 & 122.77 & 0.3 & 33.80 & 1529 & $20.4 \%$ \\
\hline
\end{tabular}

$\S$ DVR: designed void ratio.
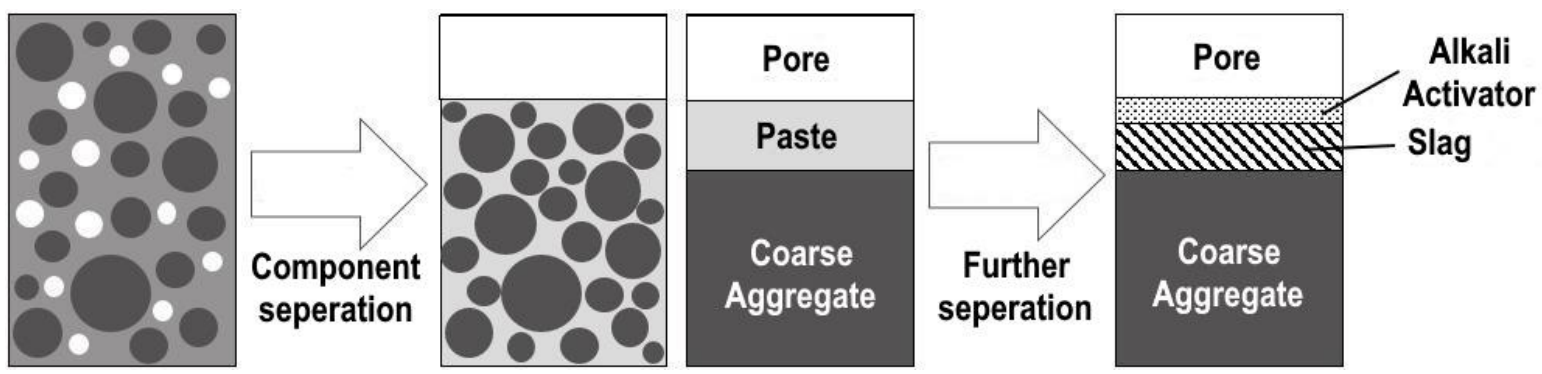

Figure 3. The method of mix design of pervious concrete used in this study.

The mix design of pervious concrete in this study can be calculated by the following equation according to the method suggested above:

$$
\frac{M_{G}}{\rho_{G}}+\frac{M_{S g}}{\rho_{S g}}+\frac{M_{W g}}{\rho_{W g}}+\frac{M_{N a O H}+M_{W}}{\rho_{N a O H} \text {,liquid }}+V_{\text {Void }}=1,
$$

where $M_{G}, M_{S g}, M_{W g}, M_{N a O H}$ and $M_{W}$ are the weight of coarse aggregate, slag, water glass, sodium hydroxide and water per cubic meter of pervious concrete $(\mathrm{kg})$, respectively; $\rho_{G}$, $\rho_{S g}, \rho_{\mathrm{Wg}}$ and $\rho_{\mathrm{NaOH} \text {,liquid }}$ are the apparent density of aggregate and slag, density of water glass and sodium hydroxide solution, respectively; and $V_{\text {Void }}$ is the designed void ratio (\%).

The activator was prepared by thoroughly mixing water glass, water, sodium hydroxide and retarder. A horizontal concrete mixer was used to prepare fresh concrete. During the preparation of pervious concrete, the coarse aggregate and slag were dry mixed at revolution speed of $62 \pm 5 \mathrm{rpm}$ and rotation speed of $140 \pm 5 \mathrm{rpm}$ for $1 \mathrm{~min}$ before the activator was added and mixed at revolution speed of $125 \pm 10 \mathrm{rpm}$ and rotation speed of $285 \pm 10 \mathrm{rpm}$ for another $2 \mathrm{~min}$. Then, the pervious concrete was transferred into moulds sized $100 \mathrm{~mm} \times 100 \mathrm{~mm} \times 100 \mathrm{~mm}$ for compressive strength test and water permeability test, and $100 \mathrm{~mm} \times 100 \mathrm{~mm} \times 400 \mathrm{~mm}$ for tensile strength test, sealed with polyethylene film and stored in the laboratory at $20 \pm 2{ }^{\circ} \mathrm{C}$ before being demoulded after 1 day of curing. 
The demoulded specimens were transferred to a curing room to be cured under standard curing conditions at a temperature of $20 \pm 2{ }^{\circ} \mathrm{C}$ and relative humidity of more than $95 \%$ $\mathrm{RH}$. The preparation of tensile strength test specimen was shown in Figure 4.

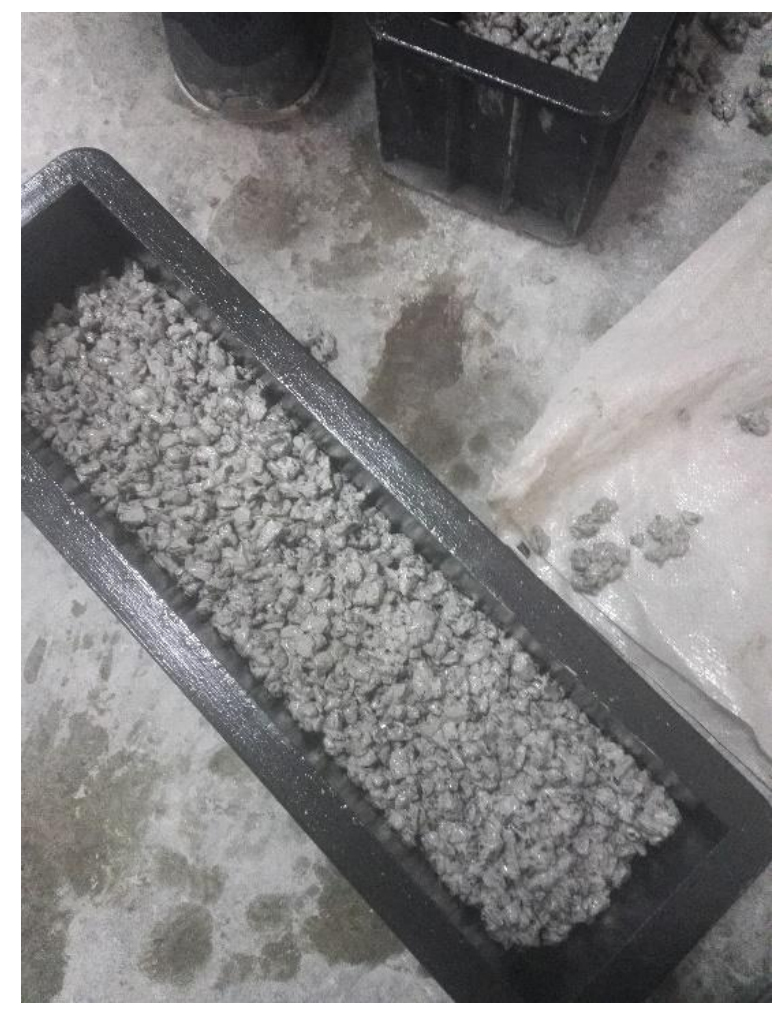

Figure 4. Preparation of tensile strength test specimen.

A laboratory cement mixer was used to prepare fresh paste. Pastes of the same mix design as those in Table 4 but without coarse aggregate were also prepared by mixing slag with activator at revolution speed of $125 \pm 10 \mathrm{rpm}$ and rotation speed of $285 \pm 10 \mathrm{rpm}$ for $2 \mathrm{~min}$ and transferring the paste into the moulds sized $40 \mathrm{~mm} \times 40 \mathrm{~mm} \times 160 \mathrm{~mm}$ for compressive and tensile strength tests. The specimens in the moulds were sealed with polyethylene film and stored in the laboratory under $20 \pm 2{ }^{\circ} \mathrm{C}$ before being demoulded after 1 day of curing. The demoulded specimens were transferred to a curing room to be cured under standard curing conditions at a temperature of $20 \pm 2{ }^{\circ} \mathrm{C}$ and relative humidity of more than $95 \% \mathrm{RH}$.

\subsubsection{Analytical Techniques}

The fluidity of fresh pastes was measured according to Chinese standard GB/T 24192005 [37] and the method used by Puertas [30]. Truncated cone for mortar fluidity test was used to measure the fluidity of alkali-activated slag in this study. Firstly, a cone sized $70 \mathrm{~mm}$ in inner diameter on top, $100 \mathrm{~mm}$ in inner diameter on bottom and $50 \mathrm{~mm}$ in height was placed on the even glass surface. Secondly, fresh paste was filled in the cone immediately after mixing. Thirdly, the cone was quickly and steadily lifted to let the paste flow on the glass surface. Finally, the diameters of two cross directions of paste were measured and the average was calculated as the fluidity of fresh paste.

The viscosity and shear stress of fresh pastes were evaluated by a Brookfield R/S-SST rotary viscosimeter with a V20 $\times 10$ vane spindle rotor from Brookfield, Middleboro, MA, USA. The pastes were firstly pre-sheared under shear speed of $15 \mathrm{~s}^{-1}$ for $30 \mathrm{~s}$, and then the measurement of rheological properties was performed as follows. The shear speed was gradually increased from $0 \mathrm{~s}^{-1}$ to $100 \mathrm{~s}^{-1}$ in $60 \mathrm{~s}$, and then the shear speed was gradually 
decreased from $100 \mathrm{~s}^{-1}$ to $0 \mathrm{~s}^{-1}$ in $60 \mathrm{~s}$. The viscosity and shear stress were analysed by Rheo2000 software (Version 2.8, Brookfield, Middleboro, MA, USA). The shear history of paste for rheology test is shown in Figure 5.

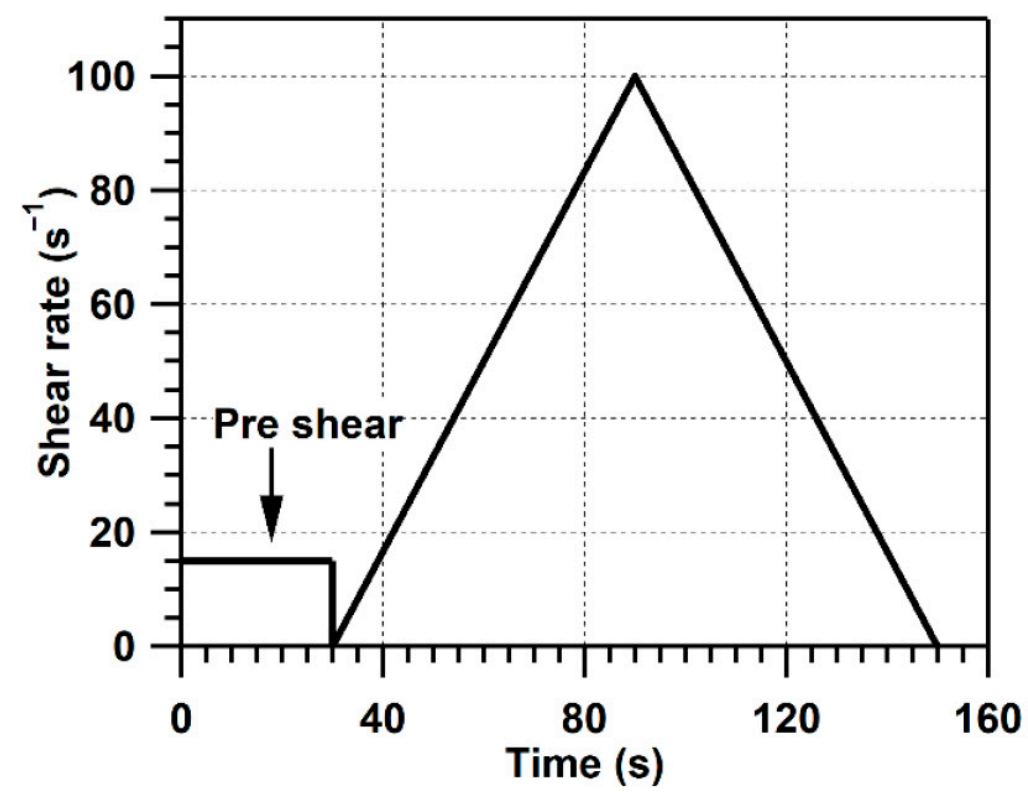

Figure 5. Shear procedure for the rheology test on the paste.

The sedimentation of paste on the bottom of pervious concrete sized $100 \mathrm{~mm} \times$ $100 \mathrm{~mm} \times 100 \mathrm{~mm}$ was evaluated by calculating the percentage of area of paste on the bottom of pervious concrete after scanning and binarizing the images on the bottom of pervious concrete as shown in Figure 6.

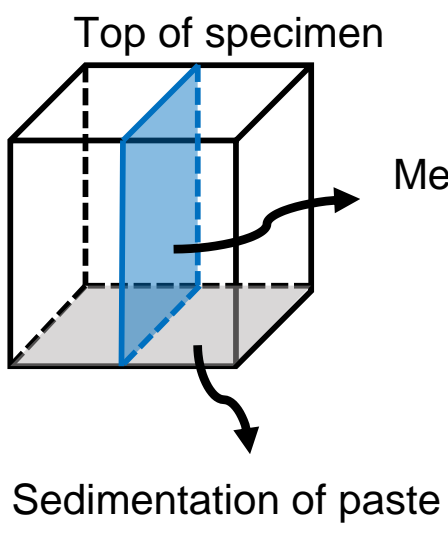

(a)

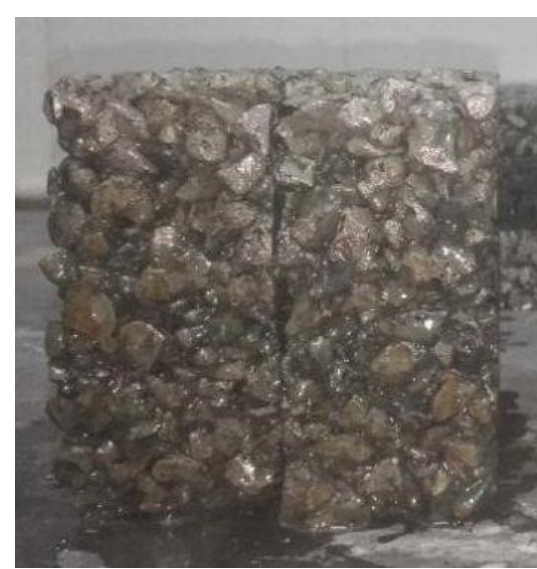

(b)

Figure 6. (a) The diagram of surfaces for sedimentation of paste and mesostructure analysis, and (b) the real specimen after cutting.

The mesostructure of pervious concrete was evaluated by vertically cutting the pervious concrete sized $100 \mathrm{~mm} \times 100 \mathrm{~mm} \times 100 \mathrm{~mm}$ (Figure 7). Then the images of cut surfaces were taken by optical microscope and analysed in ImageJ and Matlab to obtain the images of aggregate, paste and pore distribution. 


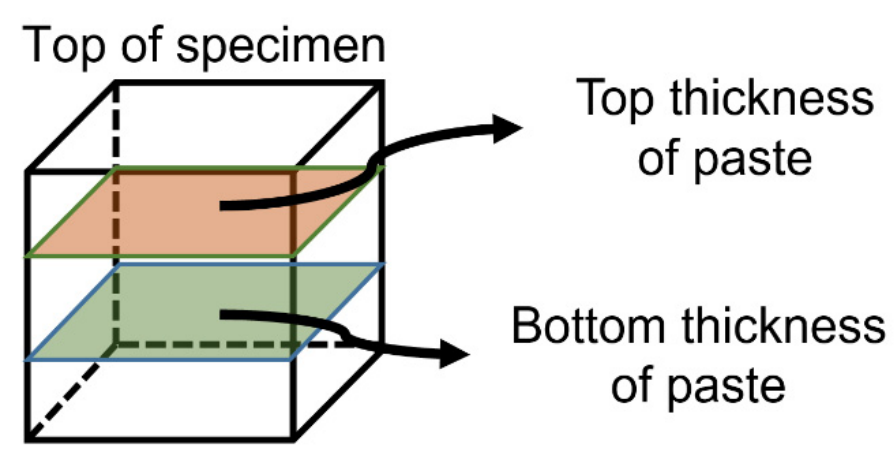

(a)

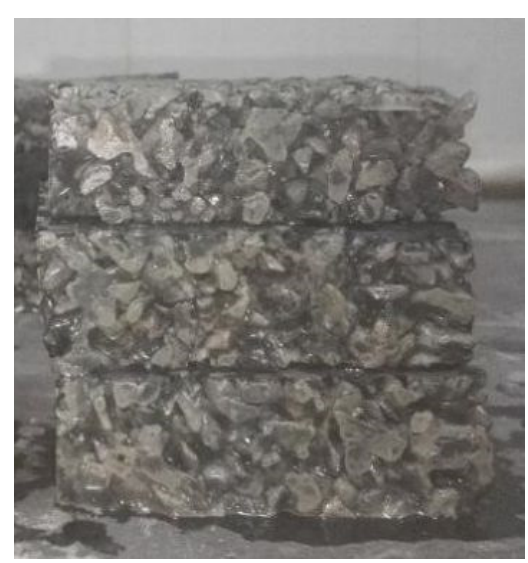

(b)

Figure 7. (a) The diagram of the method of cutting the surfaces for the thickness distribution of the paste analysis, and (b) the real specimen after cutting.

The thickness distribution of paste on the top and bottom of pervious concrete were analysed by horizontally cutting the pervious concrete at one-third and two-thirds of the height (Figure 7). Then, the thickness of paste on the coarse aggregate was measured by hand on the top and bottom cut surfaces. The methodology of measurement was the same as that reported by Torres [38]. Approximately 300 points were measured for each surface. The average thickness of each surface was calculated, and the thickness distribution was analysed.

The total porosity and connect porosity of pervious concrete were measured according to the methodology suggested by Jang [34] and multiple standards [39,40] and reports [41,42], where the total porosity, i.e., all the porosity in the pervious concrete, was suggested to correlate to the strength of pervious concrete, and the connect porosity, i.e., the pores with at least one open to the surface of pervious concrete, was suggested to correlate to the permeability of pervious concrete. Presumably, a pervious concrete with higher connect porosity could result in higher water permeability. The total porosity and connect porosity were calculated as follows:

$$
\begin{gathered}
V_{\text {connect }}=\left[1-\frac{\left(W_{2}-W_{1}\right) \rho_{W}}{V_{1}}\right] \times 100 \%, \\
V_{\text {total }}=\left[1-\frac{\left(W_{3}-W_{1}\right) \rho_{W}}{V_{1}}\right] \times 100 \%,
\end{gathered}
$$

where $W_{1}$ is the weight of specimens in water, $W_{2}$ is the weight of specimens after being dried in air for $24 \mathrm{~h}, W_{3}$ is the weight of specimens after being dried under $105^{\circ} \mathrm{C}$ for $24 \mathrm{~h}$, $V_{1}$ is the volume of specimens and $\rho_{w}$ is the density of water.

The compressive and tensile strength tests of pervious concrete were performed on the specimens cured under standard curing conditions for 28 days, according to Chinese standard JTG E30-2005 [43]. Specimens sized $100 \mathrm{~mm} \times 100 \mathrm{~mm} \times 100 \mathrm{~mm}$ were used for the compressive strength test, and those sized $100 \mathrm{~mm} \times 100 \mathrm{~mm} \times 400 \mathrm{~mm}$ were used for the tensile strength test. Three specimens were tested for each batch. The compressive strength and tensile strength were calculated by the average of three specimens.

According to Chinese standard JTG E30-2005, during the compressive strength test, the specimens were placed in the middle of the loading part of testing machine. The loading rate was set to $0.3-0.5 \mathrm{MPa} \cdot \mathrm{s}^{-1}$. Then, the force at the point of broken of specimen was recorded and the compressive strength was calculated as follows for standard-sized 150 mm cubic specimens:

$$
f_{c u}=\frac{F}{A}
$$


where $f_{c u}$ is the compressive strength (MPa), $F$ the force at the point of broken $(\mathrm{N})$ and $A$ the cross section area of specimen $\left(\mathrm{mm}^{2}\right)$.

For nonstandard-sized $100 \mathrm{~mm}$ cubic specimens, the compressive strength calculated from Equation (3) should be timed at 0.95 as the compressive strength of pervious concrete.

For the tensile strength test, the specimens were bended with three-point bending equipment and the setup is shown in Figure 8. The specimens were bended with a loading rate of $0.02-0.5 \mathrm{MPa} \cdot \mathrm{s}^{-1}$. Then, the force at the point of broken of specimen was recorded and the tensile strength was calculated by Equation (4) for standard-sized $150 \mathrm{~mm} \times$ $150 \mathrm{~mm} \times 600 \mathrm{~mm}$ specimens.

$$
f_{t}=\frac{F L}{b h^{2}}
$$

where $f_{t}$ is the tensile strength (MPa), $F$ is the force at the point of broken $(\mathrm{N}), L$ is the distance between the unmovable and moving supports $(\mathrm{mm}), b$ is the width of specimen $(\mathrm{mm})$ and $h$ is the height of specimen (mm).

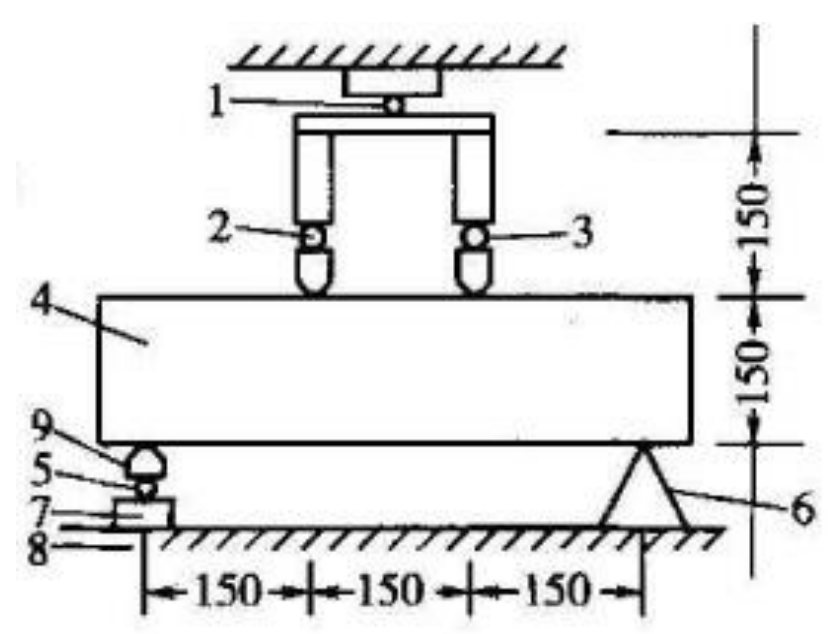

Figure 8. Setup of tensile strength test for standard-sized specimens, where 1 and 2 are single steel balls, 3 and 5 are double steel balls, 4 is the specimen, 6 is the unmovable support, 7 is the moving support, 8 is the bottom of equipment and 9 is the moving support.

For nonstandard-sized $100 \mathrm{~mm} \times 100 \mathrm{~mm} \times 400 \mathrm{~mm}$ specimens, the tensile strength calculated from Equation (4) should be timed at 0.85 as the tensile strength of pervious concrete.

Specimens sized $100 \mathrm{~mm} \times 100 \mathrm{~mm} \times 100 \mathrm{~mm}$ at 28 days were used for the water permeability test. The diagram of water permeability test is shown in Figure 9. In this study, two types of water head, namely constant head and falling head, were used to evaluate the water permeability of pervious concrete. The detailed methodology is outlined in Ref. [44].

In this study, the constant and falling head were set to $160 \mathrm{~mm}$. The water permeability of pervious concrete under constant head was calculated as follows:

$$
K=\frac{L}{h} \times \frac{Q}{A\left(t_{2}-t_{1}\right)},
$$

where $K\left(\mathrm{~mm} \cdot \mathrm{s}^{-1}\right)$ is the water permeability of pervious concrete under constant head, $L(\mathrm{~mm})$ is the length of specimen, $Q\left(\mathrm{~mm}^{3}\right)$ is the weight of water collected from the outlet during time of $t_{2}-t_{1}, h(\mathrm{~mm})$ is the water head, $t_{2}-t_{1}(\mathrm{~s})$ is the time of test and $A\left(\mathrm{~mm}^{2}\right)$ is the area of top surface of specimen. In this study, $t_{2}-t_{1}$ was set to $30 \mathrm{~s}$. 


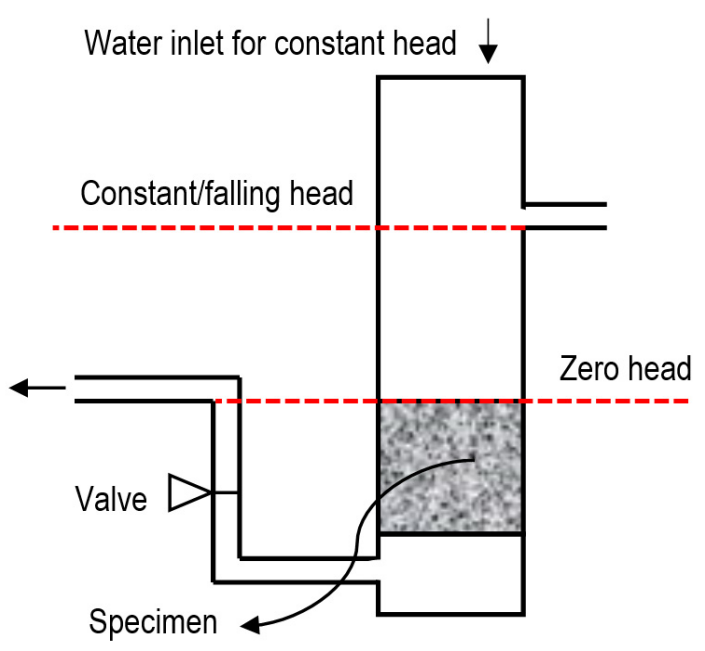

(a)

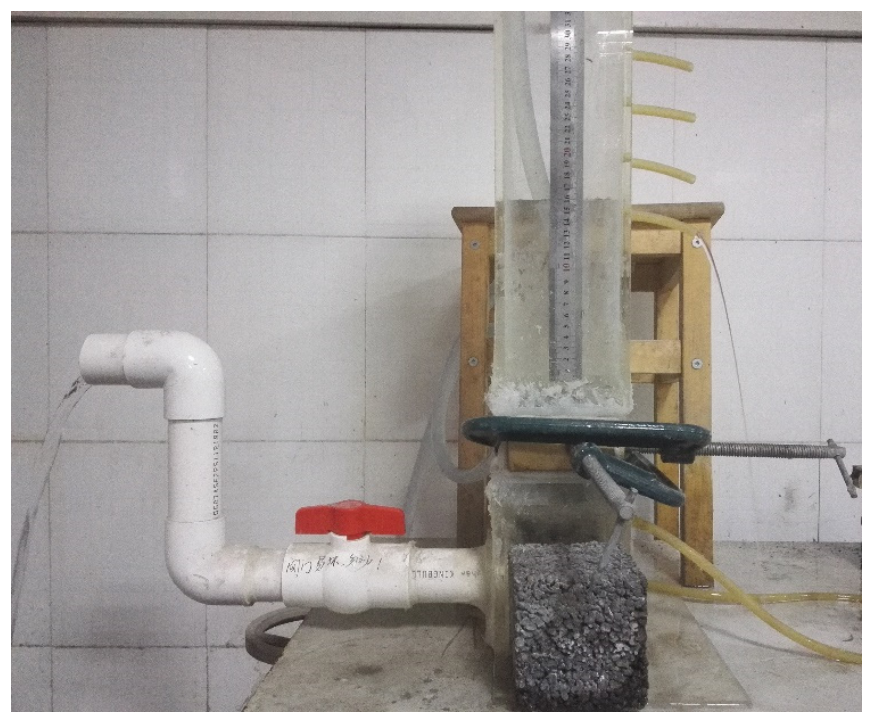

(b)

Figure 9. (a) Diagram for the setup of water permeability test for pervious concrete under constant and falling water head, and (b) the real setup.

The water permeability of pervious concrete under falling head was calculated as follows:

$$
K=\frac{A_{\text {tube }} \times L}{A \times t} \times \ln \left(\frac{h_{1}}{h_{2}}\right),
$$

where $K\left(\mathrm{~mm} \cdot \mathrm{s}^{-1}\right)$ is the water permeability of pervious concrete under falling head, $L(\mathrm{~mm})$ is the length of specimen, $A_{\text {tube }}\left(\mathrm{mm}^{2}\right)$ is the area of cross section of tube on top of specimen, $A\left(\mathrm{~mm}^{2}\right)$ is the area of cross section of specimen and $t(\mathrm{~s})$ is the time duration from the water head of $h_{1}(\mathrm{~mm})$ to $h_{2}(\mathrm{~mm})$. In this study, $h_{1}$ and $h_{2}$ were set to $160 \mathrm{~mm}$ and $50 \mathrm{~mm}$, respectively.

\section{Results and Discussion}

\subsection{Workability of Fresh Paste}

The effect of the amount of water glass on the workability of fresh paste in this study is shown in Figure 10. The fluidity gradually increased with the amount of water glass (as $\mathrm{Na}_{2} \mathrm{O}$ content) from $214 \mathrm{~mm}$ with $4 \mathrm{wt} \% \mathrm{Na}_{2} \mathrm{O}$ to $338 \mathrm{~mm}$ with $8 \mathrm{wt} \% \mathrm{Na}_{2} \mathrm{O}$, then slightly decreased to $322 \mathrm{~mm}$ with $10 \mathrm{wt} \% \mathrm{Na}_{2} \mathrm{O}$ (Figure 10a). The increase in fluidity with the water glass is due to the adsorption of silicate anions from sodium silicate on the surface of slag particles, resulting in the formation of an electric double layer separating slag particles with repulsive forces [45,46]. With the addition of $10 \mathrm{wt} \% \mathrm{Na}_{2} \mathrm{O}$, the $\mathrm{pH}$ of the liquid phase increased and became supersaturated, resulting in the formation of $\mathrm{C}-\mathrm{S}-\mathrm{H}$ gel, which in turn reduced the fluidity of the paste [45].

The development of apparent viscosity and shear stress of paste with the amount of sodium silicate addition was due to the similar reason (Figure 10b,c). The viscosity and shear stress gradually decreased with the amount of sodium silicate due to the formation of an electric double layer between the slag particles, and then decreased with the addition of $10 \mathrm{wt} \% \mathrm{Na}_{2} \mathrm{O}$ due to the supersaturation of liquid phase and formation of $\mathrm{C}-\mathrm{S}-\mathrm{H}$ gel [47] The decrease in viscosity with the increase in water glass content could also be due to the lower solid content, resulting from the higher degree of dissolution of slag with higher content of activator [48]. The sharp change at the beginning of the curve of $6 \mathrm{wt} \%$ and $10 \mathrm{wt} \%$ composition could be due to the delay during the experiments when setting the shear rate from 100 to $0 \mathrm{~s}^{-1}$ at the end of 0 to $100 \mathrm{~s}^{-1}$. 


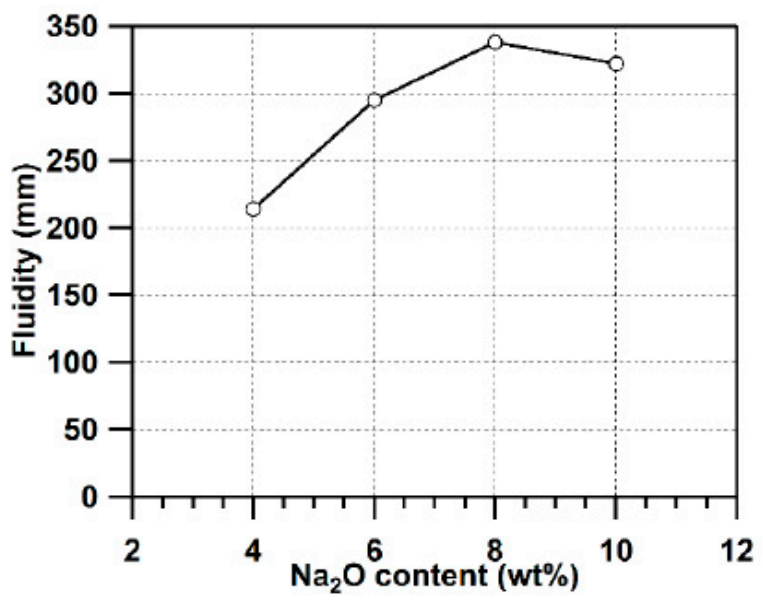

(a)

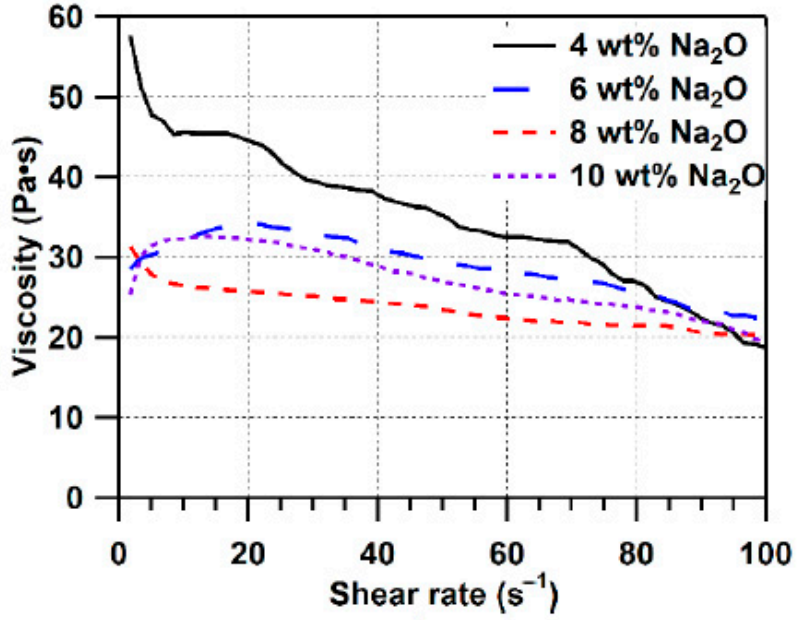

(b)

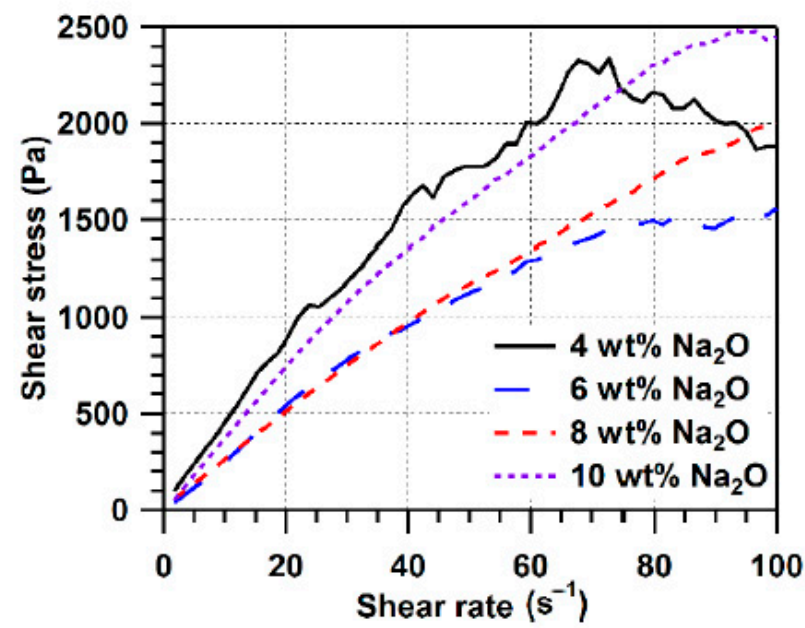

(c)

Figure 10. The relationship between the amount of water glass (as $\mathrm{Na}_{2} \mathrm{O}$ content) and (a) fluidity, (b) apparent viscosity and (c) shear stress of fresh paste.

\subsection{Sedimentation of Paste}

The fresh paste on the surface of aggregate in the pervious concrete could flow down to the bottom of the specimen due to the gravity. With a suitable rheology of fresh paste, the distribution of paste in the pervious concrete could reach homogeneity, which in turn results in the ideal mechanical properties and water permeability. The fluidity, viscosity and shear stress of fresh paste were vital to control the ideal and homogenous mechanical properties and water permeability of pervious concrete. The ideal fresh paste should form a homogenous thin layer of paste on the coarse aggregate, resulting in acceptable mechanical properties and high water permeability.

To evaluate the effect of water glass amount on the sedimentation of fresh paste in pervious concrete, the area percentage of paste and aggregate on the bottom of pervious concrete with the same amount of fresh paste was measured to identify the suitable water glass content for the pervious concrete. The optical and binary images of bottom of pervious concrete with different water glass content ( $\mathrm{as}_{\mathrm{Na}} \mathrm{O}$ content) are shown in Figure 11, and the area percentage of paste and aggregate on the bottom of pervious concrete prepared with different water glass content is shown in Figure 12. 


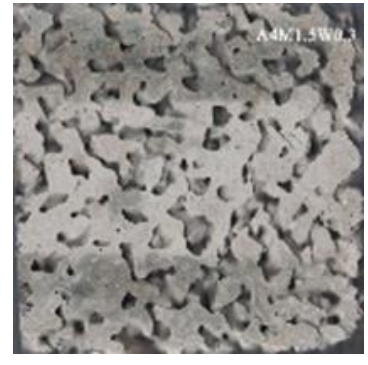

(a)

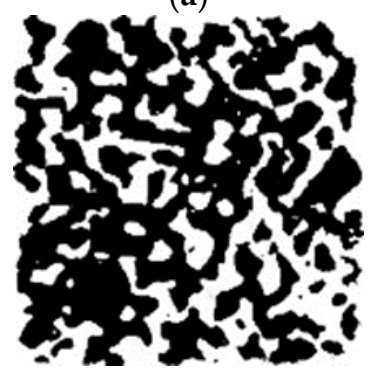

(e)

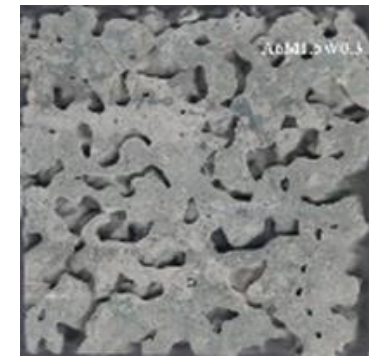

(b)

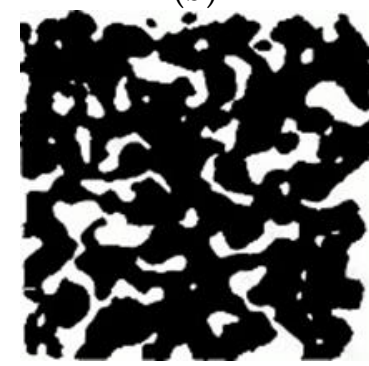

(f)

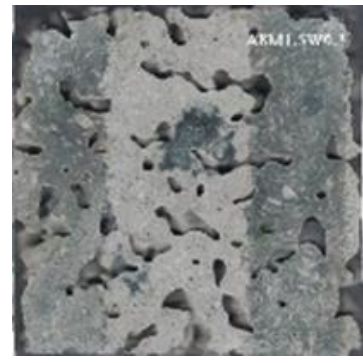

(c)

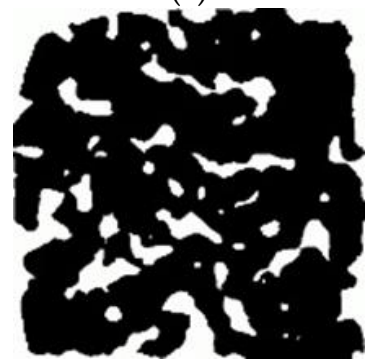

(g)

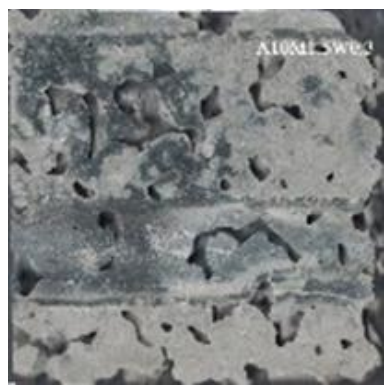

(d)

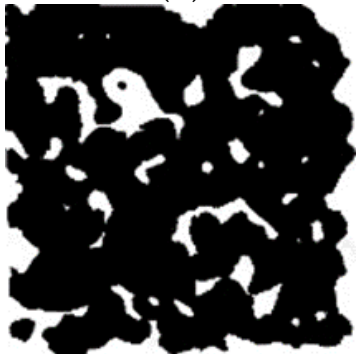

(h)

Figure 11. Optical (a-d) and respectively binary (e-h) images of the bottom of pervious concrete with different water glass content (as $\mathrm{Na}_{2} \mathrm{O}$ content). The side length of images is $100 \mathrm{~mm}$. (a,e) $4 \mathrm{wt} \% \mathrm{Na}_{2} \mathrm{O} ;(\mathbf{b}, \mathbf{f}) 6 \mathrm{wt} \% \mathrm{Na}_{2} \mathrm{O} ;(\mathbf{c}, \mathbf{g}) 8 \mathrm{wt} \% \mathrm{Na}{ }_{2} \mathrm{O}$; (d,h) $10 \mathrm{wt} \% \mathrm{Na}_{2} \mathrm{O}$.

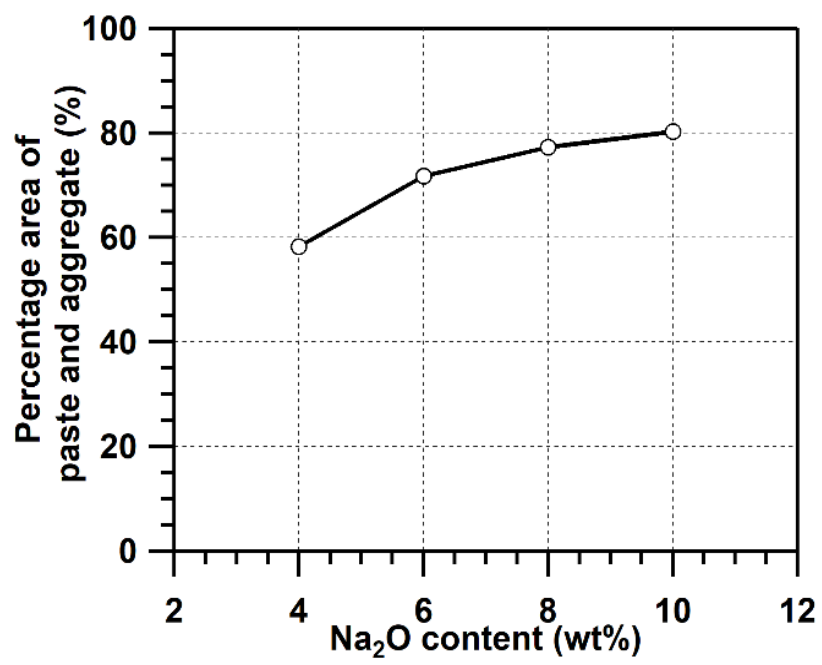

Figure 12. Sedimentation degree (as percent area of paste and aggregate) on the bottom of pervious concrete with different water glass content.

The optical and respective binary images of the bottom of pervious concrete with different water glass content are shown in Figure 11. It seems that both the pores and paste were well connected in the bottom of the pervious concrete with $4 \mathrm{wt} \% \mathrm{Na}_{2} \mathrm{O}$ content (Figure 11a,e). In addition, the sedimentation of fresh paste on the bottom of pervious concrete increased with the $\mathrm{Na}_{2} \mathrm{O}$ content (Figures $11 \mathrm{f}-\mathrm{h}$ and 12 ). The area percentage of paste and aggregate increased with the water glass content, from $58 \%$ for $4 \mathrm{wt} \%$ of $\mathrm{Na}_{2} \mathrm{O}$ to $80 \%$ for $10 \mathrm{wt} \%$ of $\mathrm{Na}_{2} \mathrm{O}$ (Figure 12 ). It seems that the degree of sedimentation is not directly related to the fluidity or viscosity but could be related to yield stress of paste. With a higher fluidity, the fresh paste is easier to flow through the space between coarse aggregates and fully cover the surface of coarse aggregate, and with a higher yield stress, the paste does not flow by gravity to the bottom of pervious concrete to result in a higher degree of sedimentation. The yield stress of fresh alkali-activated slag paste 
depends on the suspension composition, such as the composition of activator, the content of activator, the particle shape and grading [49-53]. Fresh water glass-activated slag paste can be described as Herschel-Bulkley liquid instead of Bingham liquid for fresh Portland cement paste [30]. A lower content of slag in the fresh paste could result in a lower yield stress [48], and the fresh paste with $10 \mathrm{wt} \% \mathrm{Na}_{2} \mathrm{O}$ equivalent content of water glass has the lowest slag/activator ratio, which in turn resulted in the highest sedimentation.

\subsection{Mesostructure}

The typical mesostructure of pervious concrete with $8 \mathrm{wt} \% \mathrm{Na}_{2} \mathrm{O}$ as water glass content is shown in Figure 13. The specimens of pervious concrete were vertically cut and the percentages of aggregate, paste and pore were characterized by analysing the grey scale of image of surface.

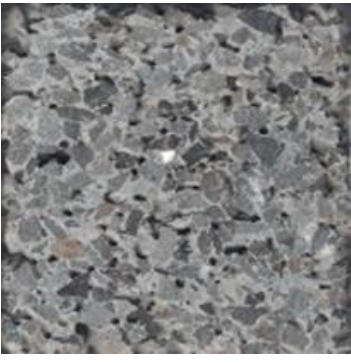

(a)

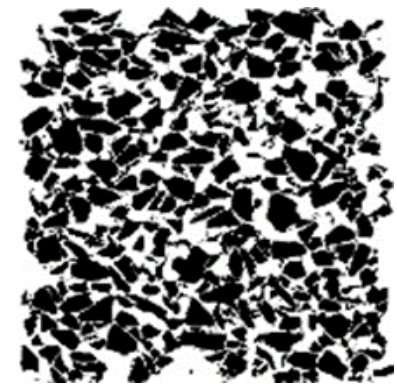

(b)

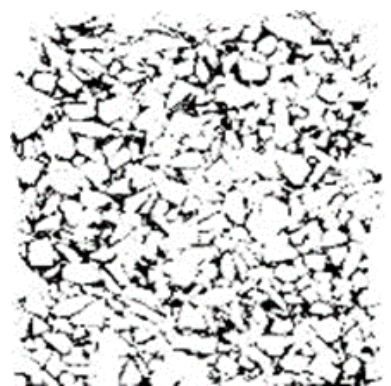

(c)

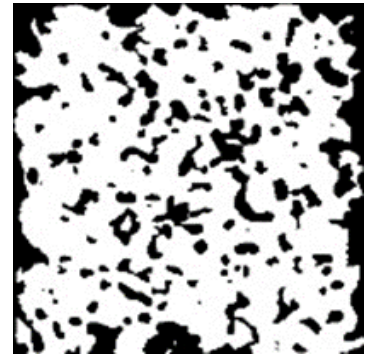

(d)

Figure 13. Typical analysis of mesostructure on the pervious concrete with $8 \mathrm{wt} \% \mathrm{Na}_{2} \mathrm{O}$ as water glass content. The side length of images is $100 \mathrm{~mm}$. (a) Optical image and binary images of (b) aggregate, (c) paste and (d) pore.

The percent areas of aggregate, paste and pore are shown in Figure 14a. The areas of aggregate were similar for all pervious concrete with different water glass content, which agrees well with the designed aggregate content, indicating that the aggregate was evenly distributed. The percent areas of paste slightly increased and those of pores decreased with the increase in water glass content in the pervious concrete. The trend of pore areas agrees with the designed void ratio, which slightly decreased with the increase in water glass content, although the calculated pore areas were higher than the designed void ratio, possibly due to the wall effect where the specimens contacted the mould, resulting in the increase in pore volume.

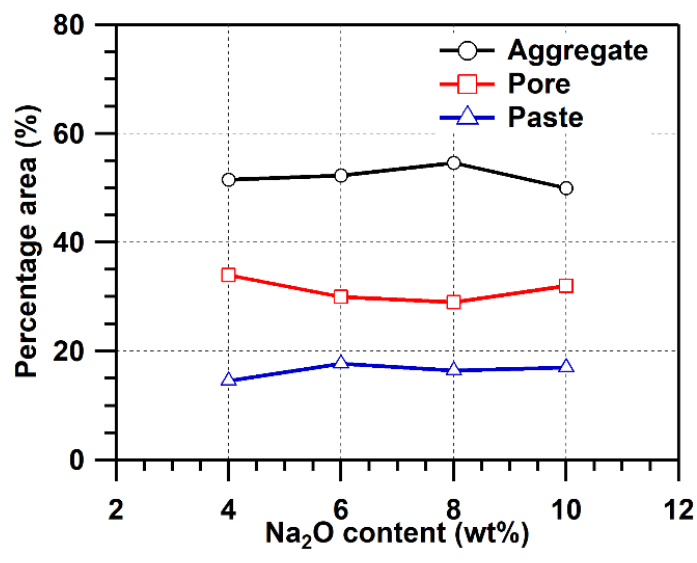

(a)

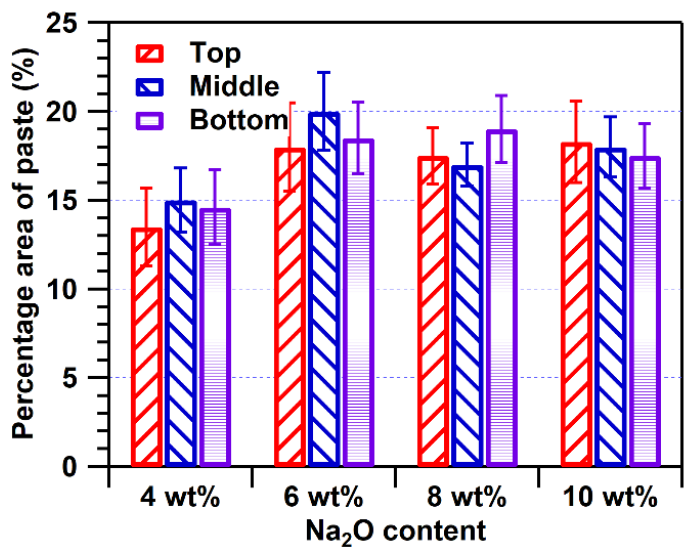

(b)

Figure 14. (a) Relationship between the water glass content and the percent area of aggregate, paste and pore on the vertically cut surface of pervious concrete; (b) percent area of paste on the top, middle and bottom parts of vertically cut surface of pervious concrete with different water glass content. 
The distribution of paste on the top, middle and bottom of vertically cut surface of pervious concrete was evaluated (Figure 14b). With the increase in water glass content, so as to the fluidity according to Figure 10a, firstly the middle areas were the highest percent areas and increased with the water glass content ( $4 \mathrm{wt} \%$ and $6 \mathrm{wt} \% \mathrm{Na}_{2} \mathrm{O}$ content), then the bottom area was the highest percent area of paste due to the increased fluidity, resulting in more sedimentation ( $8 \mathrm{wt} \% \mathrm{Na}_{2} \mathrm{O}$ content) as seen in Figures 10 and 12 . For $10 \mathrm{wt} \%$ $\mathrm{Na}_{2} \mathrm{O}$ content, the percent areas of paste on the top and middle were similar and that on the bottom was slightly lower because of the decrease in fluidity and increase in viscosity and shear stress of fresh paste according to the results from rheology of paste.

\subsection{Thickness of Paste on the Surface of Coarse Aggregate}

The thickness of paste on the surface of coarse aggregate in the pervious concrete was characterized to evaluate the homogeneity of paste and aggregate distribution. For each specimen, the thickness of paste on the top and bottom sections of pervious concrete was measured. A total of more than 300 points were measured for each specimen. According to the results in Table 5, for each mix, the average thickness of paste on the top and bottom sections was similar, with a slight increase in thickness of paste on the bottom section, which agrees well with the results from sedimentation and mesostructure analysis. The slight increase in thickness of paste could be due to the gravity which caused the flow of paste from top to bottom. These results also indicated the favoured rheology of paste, which improved the homogeneity of the thickness of paste.

Table 5. Thickness of paste on the surface of aggregate.

\begin{tabular}{|c|c|c|c|c|c|c|c|c|c|c|c|c|}
\hline & \multirow[b]{2}{*}{ Part } & \multirow[b]{2}{*}{$\mathbf{N}$} & \multirow[b]{2}{*}{ Average Thickness (mm) } & \multicolumn{9}{|c|}{ Thickness Distribution } \\
\hline & & & & $\begin{array}{c}0.2-0.6 \\
\mathrm{~mm}\end{array}$ & $\begin{array}{c}0.6-1 \\
\mathrm{~mm}\end{array}$ & $\begin{array}{c}1-1.4 \\
\mathrm{~mm}\end{array}$ & $\begin{array}{c}1.4-1.8 \\
\mathrm{~mm}\end{array}$ & $\begin{array}{c}1.8-2.2 \\
\mathrm{~mm}\end{array}$ & $\begin{array}{c}2.2-2.6 \\
\mathrm{~mm}\end{array}$ & $\begin{array}{l}2.6-3 \\
\mathrm{~mm}\end{array}$ & $\begin{array}{l}3-5 \\
\mathrm{~mm}\end{array}$ & $\begin{array}{l}\text { 5-9 } \\
\mathrm{mm}\end{array}$ \\
\hline \multirow{2}{*}{ A4 } & $\mathrm{Up}$ & 144 & 0.919 & $15 \%$ & $19 \%$ & $22 \%$ & $14 \%$ & $11 \%$ & $4 \%$ & $4 \%$ & $1 \%$ & $3 \%$ \\
\hline & Dn & 212 & 0.929 & $16 \%$ & $20 \%$ & $19 \%$ & $18 \%$ & $7 \%$ & $10 \%$ & $3 \%$ & $2 \%$ & $2 \%$ \\
\hline \multirow{2}{*}{ A6 } & $\mathrm{Up}$ & 120 & 0.941 & $3 \%$ & $27 \%$ & $20 \%$ & $22 \%$ & $8 \%$ & $3 \%$ & $3 \%$ & $5 \%$ & $0 \%$ \\
\hline & Dn & 182 & 1.003 & $8 \%$ & $20 \%$ & $15 \%$ & $29 \%$ & $11 \%$ & $7 \%$ & $3 \%$ & $7 \%$ & $0 \%$ \\
\hline \multirow{2}{*}{ A8 } & $\mathrm{Up}$ & 158 & 1.123 & $8 \%$ & $22 \%$ & $6 \%$ & $22 \%$ & $9 \%$ & $8 \%$ & $6 \%$ & $15 \%$ & $0 \%$ \\
\hline & Dn & 174 & 1.151 & $15 \%$ & $29 \%$ & $11 \%$ & $13 \%$ & $8 \%$ & $6 \%$ & $5 \%$ & $9 \%$ & $0 \%$ \\
\hline \multirow{2}{*}{ A10 } & $\mathrm{Up}$ & 132 & 1.089 & $15 \%$ & $17 \%$ & $21 \%$ & $9 \%$ & $6 \%$ & $8 \%$ & $6 \%$ & $11 \%$ & $3 \%$ \\
\hline & $\mathrm{Dn}$ & 172 & 0.965 & $10 \%$ & $27 \%$ & $20 \%$ & $15 \%$ & $10 \%$ & $5 \%$ & $2 \%$ & $7 \%$ & $1 \%$ \\
\hline
\end{tabular}

Note: Up and Dn: top and bottom of the specimens; N: number of thickness measured; Thickness distribution: percentage of points measured with thickness in the ranges.

The average thickness of paste firstly increased with the water glass content and reached the maximum of approximately $1.1 \mathrm{~mm}$ at $8 \mathrm{wt} \% \mathrm{Na}_{2} \mathrm{O}$ content, and then decreased slightly at $10 \mathrm{wt} \% \mathrm{Na}_{2} \mathrm{O}$ content (Figure 15). For all mixes, the thickness of paste on the coarse aggregate ranged from $0.919 \mathrm{~mm}$ to $1.151 \mathrm{~mm}$, indicating the similar average thickness of paste on the surface of aggregate. A previous study by Jang indicated that the average paste thickness on the surface of coarse aggregate was in the range of 1.08-1.29 mm for pervious concrete prepared with Portland cement and 0.63-4.31 mm for those with geopolymer by analysis under optical microscope under $35 \times$ magnification [34]. The results obtained in this study had a narrow range of distribution for paste thickness.

Although there was no big difference between the average thickness of paste between the mixes with the various $\mathrm{Na}_{2} \mathrm{O}$ content, the results of thickness distribution seem to reveal more information on the homogeneity of paste distribution. It seems that the mix with $6 \mathrm{wt} \% \mathrm{Na}_{2} \mathrm{O}$ content had better homogeneity of thickness of paste than other mixes. There are more points with thickness of paste close to the average thickness and less thick or thinner paste in the mix with $6 \mathrm{wt} \% \mathrm{Na}_{2} \mathrm{O}$ content. For the mix with $4 \mathrm{wt} \%$ $\mathrm{Na}_{2} \mathrm{O}$ content, there were $15 \%$ and $16 \%$ of points measured with much thinner thickness 
$(0.2-0.6 \mathrm{~mm})$ on the top and bottom of the specimen, respectively. For the mixes with $8 \mathrm{wt} \%$ and $10 \mathrm{wt} \% \mathrm{Na}_{2} \mathrm{O}$ content, there were more thinner (0.2-0.6 mm thickness) and thicker (3-5 mm thickness) layers of paste on the surface of coarse aggregate in the top and bottom of specimens. These results indicate that the homogeneity of paste in the pervious concrete is complex and controlled by many factors, such as rheology of paste. There was no clear relationship between the fluidity and homogeneity of paste in the pervious concrete.

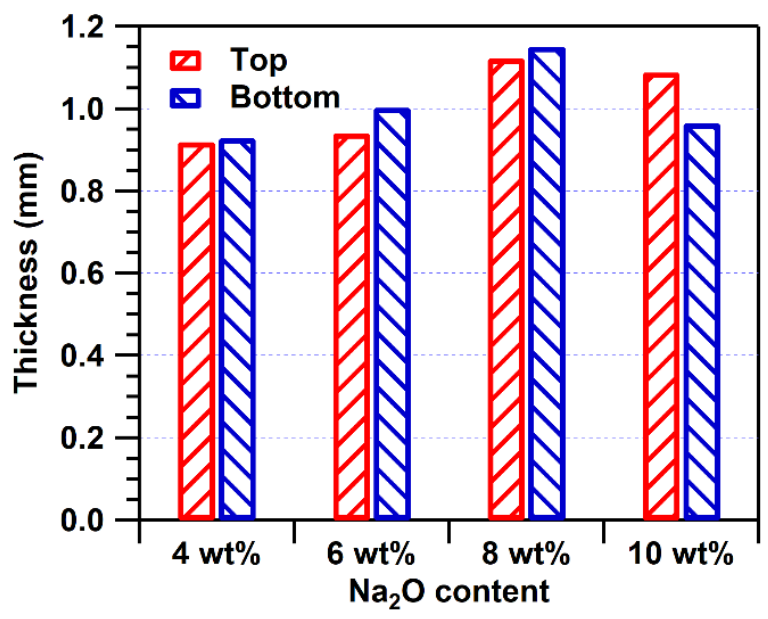

Figure 15. Thickness of paste on the surface of coarse aggregate in the pervious concrete prepared with various $\mathrm{Na}_{2} \mathrm{O}$ content.

\subsection{Strength and Water Permeability}

The compressive strength and tensile strength of alkali-activated slag prepared with different water glass content (as alkali equivalent) at 28 days are shown in Figure 16. The paste with $8 \mathrm{wt} \% \mathrm{Na}_{2} \mathrm{O}$ content had the highest compressive strength at 28 days, followed by those with $4 \mathrm{wt} \%, 6 \mathrm{wt} \%$ and $10 \mathrm{wt} \% \mathrm{Na}_{2} \mathrm{O}$ content. The tensile strength decreased with the increase in $\mathrm{Na}_{2} \mathrm{O}$ content. The reason could be due to the excess amount of $\mathrm{SiO}_{2}$ from the overdosed water glass at high water glass content. The mechanical properties of alkaliactivated slag could reach the maximum when the optimum Si/Al was satisfied [54]. Either higher or lower $\mathrm{Si} / \mathrm{Al}$ could result in lower mechanical properties. Another reason could be that the high water glass content resulted in the high $\mathrm{OH}^{-}$concentration in the paste, which in turn resulted in the thicker layer of calcium hydroxide formation on the surface of slag particles, preventing further resolution of slag particles and the formation of more hydration products $[32,55,56]$. These two reasons resulted in the decrease in mechanical properties of alkali-activated slag with higher equivalent $\mathrm{Na}_{2} \mathrm{O}$ content.

The compressive and tensile strength of pervious concrete prepared with pastes with different equivalent $\mathrm{Na}_{2} \mathrm{O}$ contents are shown in Figure 17. The trend of compressive strength of pervious concrete at 28 days was similar to that of paste. The pervious concrete prepared with paste of $4 \mathrm{wt} \%$ equivalent $\mathrm{Na}_{2} \mathrm{O}$ content had the highest compressive strength among the specimens studied, which is followed by those of $6 \mathrm{wt} \%, 8 \mathrm{wt} \%$ and $10 \mathrm{wt} \%$ equivalent $\mathrm{Na}_{2} \mathrm{O}$ content. For the tensile strength of pervious concrete with $4 \mathrm{wt} \% \mathrm{Na}_{2} \mathrm{O}$, the specimens showed similar tensile strength of approximately $3.5 \mathrm{MPa}$ at 28 days. The mechanical properties of pervious concrete were controlled not only by the properties of cementitious materials but also by the pore structures, especially macroand mesopore structures. There was correlation between the mechanical properties of paste and that of pervious concrete. It is interesting that there is no correlation between the compressive strength and the tensile strength of either paste or pervious concrete, indicating a different mechanism behind the mechanical properties between pervious concrete and normal concrete. The relationship between the thickness distribution of paste on the coarse aggregate and the mechanical properties of pervious concrete warrant further study. 


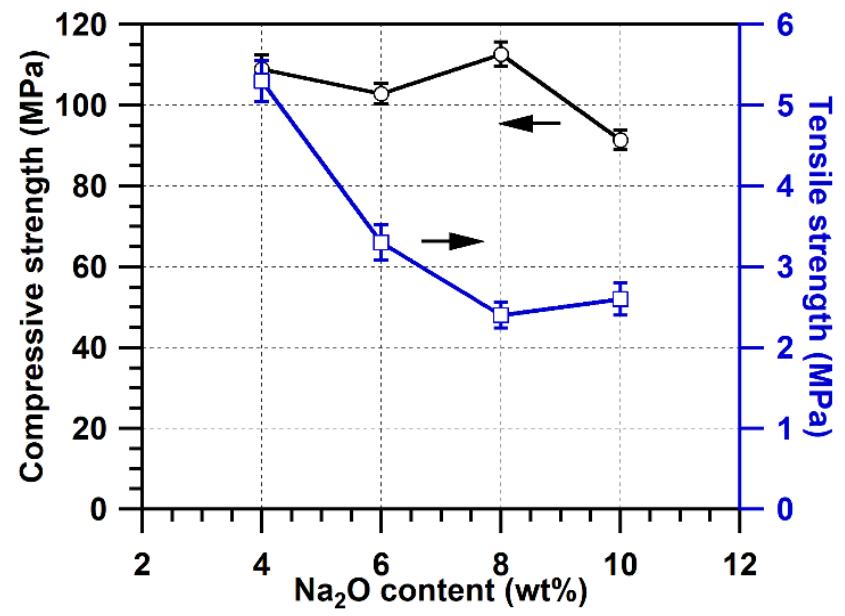

Figure 16. Compressive strength and tensile strength of alkali-activated slag paste with different water glass content (as alkali equivalent) at 28 days.

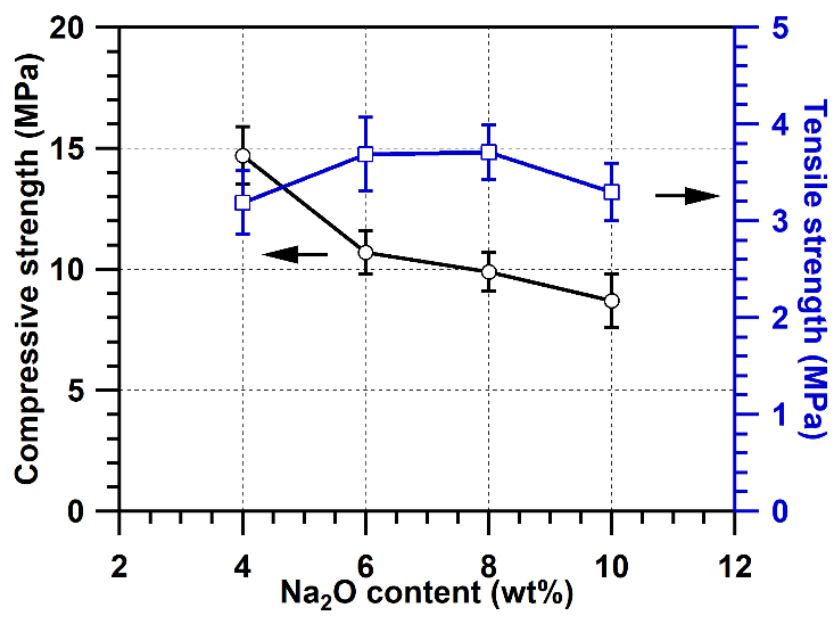

Figure 17. Compressive strength and tensile strength of pervious concrete prepared with various equivalent $\mathrm{Na}_{2} \mathrm{O}$ content at 28 days.

For normal cement-based pervious concrete, the porosity of pervious concrete greatly affects the mechanical properties, and the other differences in properties/components also result in the variation of mechanical properties, such as the type and size of aggregate, the type and content of cement and admixtures, the formula of cementitious materials and the water/cement ratio. Generally, for cement-based pervious concrete, the permeability is $0.2-7.0 \mathrm{~cm} / \mathrm{s}$, the porosity is $15-35 \%$, and the compressive strength is 5-30 MPa [1,2,6-9].

The DVR, total porosity and connect porosity of pervious concrete at 28 days are shown in Figure 18. There are similar trends for the DVR and total porosity measured, with a slightly higher porosity for the latter. The total porosity decreased with the increase in equivalent $\mathrm{Na}_{2} \mathrm{O}$ content of paste. It is interesting that the trend of total porosity is similar to that of compressive strength of pervious concrete. Usually, the higher porosity indicates lower compressive strength for concrete. These results suggested that the relationship between the compressive strength, total porosity and thickness distribution of paste on the surface of coarse aggregate is more complex than expected. The total porosity from other previous studies ranges from $31 \%$ to $45 \%$, with the compressive strength of 1.1-6.45 MPa [55,56]. The pervious concrete in this study had lower total porosity but much higher compressive strength. As suggested by Barnhous and Srubar III [55], the permeability could be sharply increased with porosity when the porosity is over $30 \%$ 
but together with a decrease in compressive strength. The design of pervious concrete is basically a balance between the compressive/tensile strength and permeability.

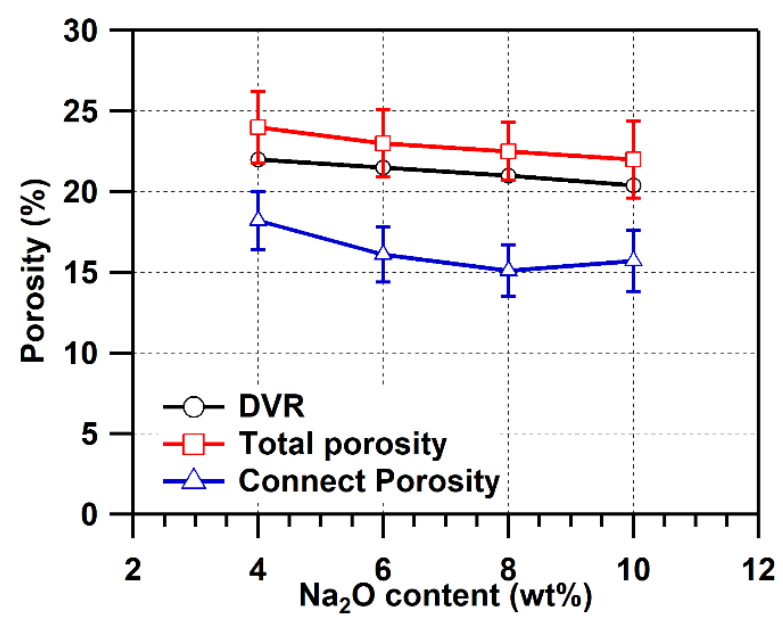

Figure 18. The DVR (designed voids ratio), total porosity and connect porosity of pervious concrete with paste of various equivalent $\mathrm{Na}_{2} \mathrm{O}$ content at 28 days.

The connect porosity of pervious concrete had a similar trend of total porosity, except that the connect porosity of pervious concrete with paste of $10 \mathrm{wt} \% \mathrm{Na}_{2} \mathrm{O}$ content was slightly higher than that of $8 \mathrm{wt} \% \mathrm{Na}_{2} \mathrm{O}$ content. The connect porosity is a defining factor for the water permeability of pervious concrete. According to the water permeability results of pervious concrete in Figure 19, the water permeability of pervious concrete under both falling head and constant head decreased with the increase in equivalent $\mathrm{Na}_{2} \mathrm{O}$ content of paste, which agrees well with the trend of connect porosity of pervious concrete. These results are reasonable because water can only permeate through the pervious concrete by the connected pore, which was characterized as connect porosity. There is a correlation between the connected porosity, water permeability and tensile strength of pervious concrete, which all decreased with the increase in equivalent alkali content by up to $8 \mathrm{wt} \% \mathrm{Na}_{2} \mathrm{O}$ and slightly decreased when $\mathrm{Na}_{2} \mathrm{O}$ content reached $10 \mathrm{wt} \%$. A previous study [34] on the porosity of pervious concrete prepared with geopolymer indicated that the pervious concrete with a total porosity of $24.1-40.2 \%$ had connect porosity of $18.4-34.1 \%$, together with a lower compressive strength compared with this study. A higher total porosity usually results in a lower compressive strength for concrete.

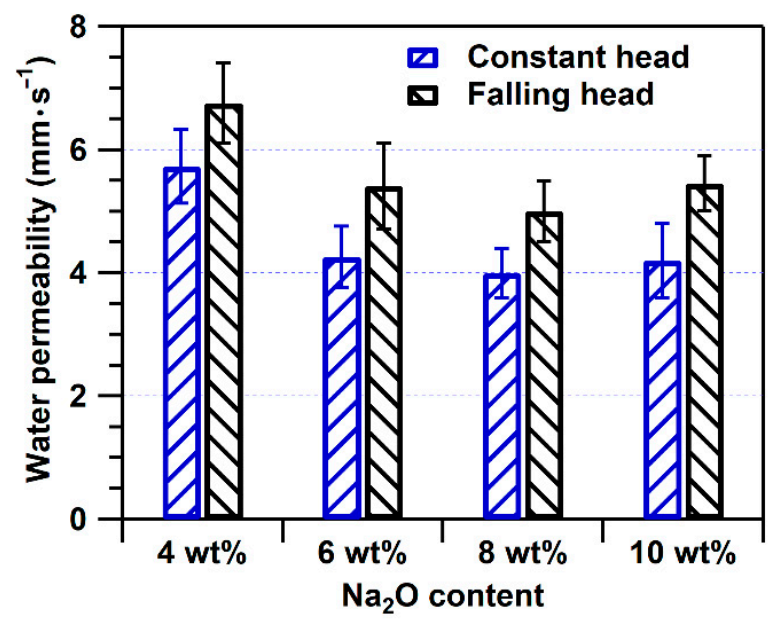

Figure 19. Water permeability of pervious concrete under falling head and constant head. 
The intrinsic permeability based on Darcy's law can be descripted as the following equations:

$$
\begin{gathered}
Q=-K A \frac{\Delta h}{L}, \\
K=k \frac{\rho g}{\eta},
\end{gathered}
$$

where $Q$ is the total discharge rate $\left(\mathrm{m}^{3} / \mathrm{s}\right) ; K$ is the hydraulic conductivity $(\mathrm{m} / \mathrm{s}) ; A$ is the area of cross section of the flume $\left(\mathrm{m}^{2}\right)$, which is the cross section area of specimen of pervious concrete in the manuscript; $\Delta h$ is the height difference $(\mathrm{m})$, which is the water head in the manuscript; $L$ is the length of specimen of pervious concrete in the manuscript $(\mathrm{m}) ; k$ is the intrinsic permeability $\left(\mathrm{m}^{2}\right) ; \rho$ is the density of fluid $\left(\mathrm{kg} / \mathrm{m}^{3}\right) ; g$ is the gravity $\left(\mathrm{m} / \mathrm{s}^{2}\right) ; \eta$ is the dynamic viscosity of the fluid (Pa.s).

The term "water permeability" used in this study is hydraulic conductivity in Darcy's law, which is used to descript how easily the water can move through the connected pores in the pervious concrete. The intrinsic permeability can be calculated from hydraulic conductivity according to Equation (9). Considering that only water permeates through pervious concrete under normal atmospheric pressure and the temperature for the test was $20^{\circ} \mathrm{C}$, the hydraulic conductivity is usually used to describe the permeability of pervious concrete, which is termed as water permeability in the field of cement and concrete research. The relationship between these two is as follows:

$$
K=9.75 \times 10^{6} \cdot k
$$

\section{Conclusions}

In this study, pervious concrete was prepared with high fluidity alkali-activated slag of various alkali equivalent. The effect of alkali equivalent on the fluidity and sedimentation of paste, pore structure, mechanical properties and water permeability of pervious concrete was characterized by a range of analytical techniques. According to the results obtained, the following conclusions can be drawn.

The fluidity of water glass-activated slag increased with the equivalent alkali content by up to $8 \mathrm{wt} \% \mathrm{Na}_{2} \mathrm{O}$ content and slightly decreased by $10 \mathrm{wt} \% \mathrm{Na}_{2} \mathrm{O}$ content, while the effect of equivalent alkali content on the viscosity and shear stress of fresh pastes was more complex, where the viscosity and shear stress firstly decreased with the increase in equivalent alkali content and then increased when equivalent alkali content increased to $10 \mathrm{wt} \% \mathrm{Na}_{2} \mathrm{O}$ content under a shear rate of $20-80 \mathrm{~s}^{-1}$. With a shear rate over $80 \mathrm{~s}^{-1}$, the viscosity and shear stress drastically decreased for paste with $4 \mathrm{wt} \% \mathrm{Na}_{2} \mathrm{O}$ content.

The sedimentation of fresh paste on the bottom of pervious concrete was related to the rheology of fresh paste, which had a similar trend to that of fluidity. A higher fluidity and lower viscosity and shear stress will result in a more severe sedimentation of fresh paste on the bottom of pervious concrete, which worsens the homogeneity of mesostructure of pervious concrete, resulting in lower tensile strength and water permeability.

The percentage area of paste and the average thickness of paste on the surface of coarse aggregate had a similar trend to that of fluidity, which increased with the equivalent alkali content and slightly decreased when the $\mathrm{Na}_{2} \mathrm{O}$ content reached $10 \mathrm{wt} \%$. There was a relationship between the compressive strength with the percentage area of paste or the average thickness of paste on the surface of coarse aggregate, but there was no obvious relationship for the tensile strength with the latter.

The water permeability of pervious concrete was governed by the connected porosity, which had good correlation with the tensile strength. A relative lower fluidity, higher viscosity and shear stress of fresh alkali-activated slag paste favoured lower sedimentation of paste on the bottom of pervious concrete, higher connected porosity, tensile strength and water permeability. 
The findings in this study are potentially beneficial for the optimized design of pervious concrete prepared with alkali-activated materials, especially in the application of pavement, where the tensile strength is more important than compressive strength.

Author Contributions: Conceptualization, Q.L. and S.B.D.; methodology, Q.L., H.G. and Q.X.; software, Q.X.; validation, H.G., Q.X., S.B.D. and Q.L.; formal analysis, H.G. and Q.X.; investigation, H.G. and Q.X.; resources, Q.L.; data curation, H.G. and Q.X.; writing—original draft preparation, H.G.; writing-review and editing, H.G., Q.X., S.B.D. and Q.L.; visualization, Q.L.; supervision, Q.L.; project administration, Q.L. and H.G.; funding acquisition, Q.L. All authors have read and agreed to the published version of the manuscript.

Funding: This research was funded by State Key Laboratory of Silicate Materials for Architectures (Wuhan University of Technology), China.

Institutional Review Board Statement: Not applicable.

Informed Consent Statement: Not applicable.

Data Availability Statement: The data presented in this study are available within the article.

Acknowledgments: This research was financially supported by the State Key Laboratory of Silicate Materials for Architectures (Wuhan University of Technology), China.

Conflicts of Interest: The authors declare no conflict of interest. The funders had no role in the design of the study; in the collection, analyses, or interpretation of data; in the writing of the manuscript, or in the decision to publish the results.

\section{References}

1. Cosic, K.; Korat, L.; Ducman, V.; Netinger, I. Influence of aggregate type and size on properties of pervious concrete. Constr. Build. Mater. 2015, 78, 69-76. [CrossRef]

2. Chen, Y.; Wang, K.; Wang, X.; Zhou, W. Strength, fracture and fatigue of pervious concrete. Constr. Build. Mater. 2013, 42, 97-104. [CrossRef]

3. Chen, Y.; Wang, K.-J.; Liang, D. Mechanical properties of pervious cement concrete. J. Cent. South Univ. 2012, 19, 3329-3334. [CrossRef]

4. Sata, V.; Wongsa, A.; Chindaprasirt, P. Properties of pervious geopolymer concrete using recycled aggregates. Constr. Build. Mater. 2013, 42, 33-39. [CrossRef]

5. Tho-in, T.; Sata, V.; Chindaprasirt, P.; Jaturapitakkul, C. Pervious high-calcium fly ash geopolymer concrete. Constr. Build. Mater. 2012, 30, 366-371. [CrossRef]

6. Chandrappa, A.K.; Biligiri, K.P. Comprehensive investigation of permeability characteristics of pervious concrete: A hydrodynamic approach. Constr. Build. Mater. 2016, 123, 627-637. [CrossRef]

7. Kim, Y.J.; Gaddafi, A.; Yoshitake, I. Permeable concrete mixed with various admixtures. Mater. Des. 2016, 100, 110-119. [CrossRef]

8. Chang, J.J.; Yeih, W.; Fu, T.C.; Huang, R. Properties of pervious concrete made with electric arc furnace slag and alkali-activated slag cement. Constr. Build. Mater. 2016, 109, 34-40. [CrossRef]

9. Wu, H.; Liu, Z.; Sun, B.; Yin, J. Experimental investigation on freeze-thaw durability of Portland cement pervious concrete (PCPC). Constr. Build. Mater. 2016, 117, 63-71. [CrossRef]

10. Dong, Q.; Wu, H.; Huang, B.; Shu, X.; Wang, K. Investigation into Laboratory Abrasion Test Methods for Pervious Concrete. J. Mater. Civ. Eng. 2013, 25, 886-892. [CrossRef]

11. Haselbach, L.; Poor, C.; Tilson, J. Dissolved zinc and copper retention from stormwater runoff in ordinary portland cement pervious concrete. Constr. Build. Mater. 2014, 53, 652-657. [CrossRef]

12. Kim, G.M.; Jang, J.G.; Khalid, H.R.; Lee, H.K. Water purification characteristics of pervious concrete fabricated with CSA cement and bottom ash aggregates. Constr. Build. Mater. 2017, 136, 1-8. [CrossRef]

13. Jo, M.; Soto, L.; Arocho, M.; St John, J.; Hwang, S. Optimum mix design of fly ash geopolymer paste and its use in pervious concrete for removal of fecal coliforms and phosphorus in water. Constr. Build. Mater. 2015, 93, 1097-1104. [CrossRef]

14. Yeih, W.; Fu, T.C.; Chang, J.J.; Huang, R. Properties of pervious concrete made with air-cooling electric arc furnace slag as aggregates. Constr. Build. Mater. 2015, 93, 737-745. [CrossRef]

15. Zaetang, Y.; Wongsa, A.; Sata, V.; Chindaprasirt, P. Use of coal ash as geopolymer binder and coarse aggregate in pervious concrete. Constr. Build. Mater. 2015, 96, 289-295. [CrossRef]

16. Duxson, P.; Fernandez-Jimenez, A.; Provis, J.L.; Lukey, G.C.; Palomo, A.; van Deventer, J.S.J. Geopolymer technology: The current state of the art. J. Mater. Sci. 2007, 42, 2917-2933. [CrossRef]

17. Provis, J.L.; van Deventer, J.S.J. Geopolymerisation kinetics. 1. In situ energy-dispersive X-ray diffractometry. Chem. Eng. Sci. 2007, 62, 2309-2317. [CrossRef] 
18. Provis, J.L.; Walls, P.A.; van Deventer, J.S.J. Geopolymerisation kinetics. 3. Effects of Cs and Sr salts. Chem. Eng. Sci. 2008, 63, 4480-4489. [CrossRef]

19. Provis, J.L. Geopolymers and other alkali activated materials: Why, how, and what? Mater. Struct. 2014, 47, 11-25. [CrossRef]

20. Provis, J.L.; Bernal, S.A. Geopolymers and Related Alkali-Activated Materials. In Annual Review of Materials Research; Clarke, D.R., Ed.; Annual Reviews; Palo Alto: Santa Clara, CA, USA, 2014; Volume 44, pp. 299-327.

21. Duxson, P.; Provis, J.L.; Lukey, G.C.; Van Deventer, J.S.J. The role of inorganic polymer technology in the development of 'green concrete'. Cem. Concr. Res. 2007, 37, 1590-1597. [CrossRef]

22. Torres-Carrasco, M.; Puertas, F. Alkaline activation of aluminosilicates as an alternative to portland cement: A review. Rev. Romana Mater. Rom. J. Mater. 2017, 47, 3-15.

23. Bernal, S.A.; Provis, J.L. Durability of Alkali-Activated Materials: Progress and Perspectives. J. Am. Ceram. Soc. 2014, 97, 997-1008. [CrossRef]

24. Attwell, C. Geopolymer concrete: A practical approach. Constr. Mater. Struct. 2014, 466-474. [CrossRef]

25. Majidi, B. Geopolymer technology, from fundamentals to advanced applications: A review. Mater. Technol. 2009, $24,79-87$. [CrossRef]

26. Zhang, Z.H.; Provis, J.L.; Zou, J.; Reid, A.; Wang, H. Toward an indexing approach to evaluate fly ashes for geopolymer manufacture. Cem. Concr. Res. 2016, 85, 163-173. [CrossRef]

27. Aydin, S.; Baradan, B. Effect of activator type and content on properties of alkali-activated slag mortars. Compos. Part B Eng. 2014, 57, 166-172. [CrossRef]

28. Provis, J.L. Green concrete or red herring?-future of alkali-activated materials. Adv. Appl. Ceram. 2014, 113, 472-477. [CrossRef]

29. Provis, J.L.; Palomo, A.; Shi, C.J. Advances in understanding alkali-activated materials. Cem. Concr. Res. 2015, 78, 110-125. [CrossRef]

30. Puertas, F.; Varga, C.; Alonso, M.M. Rheology of alkali-activated slag pastes. Effect of the nature and concentration of the activating solution. Cem. Concr. Compos. 2014, 53, 279-288. [CrossRef]

31. Navarro, R.; Zornoza, E.; Garces, P.; Sanches, I.; Alcocel, E.G. Optimization of the alkali activation conditions of ground granulated SiMn slag. Constr. Build. Mater. 2017, 150, 781-791. [CrossRef]

32. Marjanovic, N.; Komljenovic, M.; Bascarevic, Z.; Nikolic, V.; Petrovic, R. Physical-mechanical and microstructural properties of alkali-activated fly ash-blast furnace slag blends. Ceram. Int. 2015, 41, 1421-1435. [CrossRef]

33. Wang, W.C.; Wang, H.Y.; Tsai, H.C. Study on engineering properties of alkali-activated ladle furnace slag geopolymer. Constr. Build. Mater. 2016, 123, 800-805. [CrossRef]

34. Jang, J.G.; Ahn, Y.B.; Souri, H.; Lee, H.K. A novel eco-friendly porous concrete fabricated with coal ash and geopolymeric binder: Heavy metal leaching characteristics and compressive strength. Constr. Build. Mater. 2015, 79, 173-181. [CrossRef]

35. GB/T 14685-2011: Pebble and Crushed Stone for Construction; Standardization Administration of the People's Republic of China: Beijing, China, 2011.

36. Sun, H. Mix Design and Properties of Pervious Concrete Based on the Optimization Method; Southwest Jiaotong University: Chengdu, China, 2016.

37. GB/T 2419-2005: Test Method for Fluidity of Cement Mortar; National Standardization Administration Commission: Beijing, China, 2005.

38. Torres, A.; Hu, J.; Ramos, A. The effect of the cementitious paste thickness on the performance of pervious concrete. Constr. Build. Mater. 2015, 95, 850-859. [CrossRef]

39. DB11/T 775-2010: Technical Specification for Pervious Concrete Pavement; Quality Supervision Bureau of Beijing: Beijing, China, 2010.

40. International, A. ASTM C1754/C1754M-12: Standard Test Method for Density and Void Content of Hardened Pervious Concrete; ASTM International: West Conshohocken, PA, USA, 2012.

41. Japanese Concrete Institute. Technical Committee Report on Eco-Concrete; Japanese Concrete Institute: Tokyo, Japan, 1995.

42. Japanese Concrete Institute. Technical Committee Report on Design and Construction of Porous Concrete; Japanese Concrete Institute: Tokyo, Japan, 2003.

43. JTG E30-2005: Test Methods of Cement and Concrete for Highway Engineering; Ministry of Transport of the People's Republic of China: Beijing, China, 2005.

44. Dang Hanh, N.; Boutouil, M.; Sebaibi, N.; Leleyter, L.; Baraud, F. Valorization of seashell by-products in pervious concrete pavers. Constr. Build. Mater. 2013, 49, 151-160. [CrossRef]

45. Kashani, A.; Provis, J.L.; Qiao, G.G.; van Deventer, J.S.J. The interrelationship between surface chemistry and rheology in alkali activated slag paste. Constr. Build. Mater. 2014, 65, 583-591. [CrossRef]

46. Provis, J.L.; Bernal, S.A. Alkali-activated binders-chemistry and engineering. In Advances in Chemically-Activated Materials; Shi, C., Shen, X., Eds.; RILEM Publications: Bagneux, France, 2014; Volume 92, p. 3.

47. Ravikumar, D.; Neithalath, N. Effects of activator characteristics on the reaction product formation in slag binders activated using alkali silicate powder and $\mathrm{NaOH}$. Cem. Concr. Compos. 2012, 34, 809-818. [CrossRef]

48. Beersaerts, G.; Vananroye, A.; Sakellariou, D.; Clasen, C.; Pontikes, Y. Rheology of an alkali-activated Fe-rich slag suspension: Identifying the impact of the activator chemistry and slag particle interactions. J. Non-Cryst. Solids 2021, 561, 120747. [CrossRef]

49. Aminul Islam, L.; Rajan, B. Rheology of Fly-Ash-Based Geopolymer Concrete. ACI Mater. J. 2011, 108. [CrossRef] 
50. Alonso, M.M.; Gismera, S.; Blanco, M.T.; Lanzón, M.; Puertas, F. Alkali-activated mortars: Workability and rheological behaviour. Constr. Build. Mater. 2017, 145, 576-587. [CrossRef]

51. Bentz, D.P.; Ferraris, C.F.; Galler, M.A.; Hansen, A.S.; Guynn, J.M. Influence of particle size distributions on yield stress and viscosity of cement-fly ash pastes. Cem. Concr. Res. 2012, 42, 404-409. [CrossRef]

52. Vance, K.; Dakhane, A.; Sant, G.; Neithalath, N. Observations on the rheological response of alkali activated fly ash suspensions: The role of activator type and concentration. Rheol. Acta 2014, 53, 843-855. [CrossRef]

53. Duxson, P.; Provis, J.L.; Lukey, G.C.; Mallicoat, S.W.; Kriven, W.M.; van Deventer, J.S.J. Understanding the relationship between geopolymer composition, microstructure and mechanical properties. Colloids Surf. A Physicochem. Eng. Asp. 2005, $269,47-58$. [CrossRef]

54. Brough, A.R.; Holloway, M.; Sykes, J.; Atkinson, A. Sodium silicate-based alkali-activated slag mortars Part II. The retarding effect of additions of sodium chloride or malic acid. Cem. Concr. Res. 2000, 30, 1375-1379. [CrossRef]

55. Rimer, J.D.; Lobo, R.F.; Vlachos, D.G. Physical basis for the formation and stability of silica nanoparticles in basic solutions of monovalent cations. Langmuir 2005, 21, 8960-8971. [CrossRef]

56. Barnhouse, P.W.; Srubar, W.V. Material characterization and hydraulic conductivity modeling of macroporous recycled-aggregate pervious concrete. Constr. Build. Mater. 2016, 110, 89-97. [CrossRef] 